DOI: 10 12962/i26139960 v5i3.28 $\quad$ Naskah Masuk 10-02-2021; $\quad$ Naskah Diulas 03-05-2021; $\quad$ Naskah Diterima 03-05-2021

NASKAH ORISINAL

\title{
Pemanfaatan Limbah Kulit Kerang dan Limbah Sisa Pengolahan Ikan di Kecamatan Bulak Kota Surabaya
}

Nova Maulidina Ashuri*1 I Awik Puji Dyah Nurhayati ${ }^{1}$ I IDAA Warmadewanthi ${ }^{2}$ I Dian Saptarini $^{1}$ | Ary Bachtiar Krishna Putra ${ }^{3}$ | Arseto Yekti Bagastyo ${ }^{2}$ | Welly Herumurti ${ }^{2}$ | Annisya Fitri Rachmada $^{1}$ 
${ }^{1}$ Departemen Biologi, Institut Teknologi Sepuluh Nopember, Surabaya, Indonesia

${ }^{2}$ Departemen Teknik Lingkungan, Institut Teknologi Sepuluh Nopember, Surabaya, Indonesia

${ }^{3}$ Departemen Teknik Mesin, Institut Teknologi Sepuluh Nopember, Surabaya, Indonesia

\section{Korespondensi}

*Nova Maulidina Ashuri, Departemen Biologi, Institut Teknologi Sepuluh Nopember, Surabaya, Indonesia. Alamat e-mail:maulidina@bio.its.ac.id

\section{Alamat \\ Gedung H, Departemen Biologi, Institut Teknologi Sepuluh Nopember, Surabaya, Indonesia}

\begin{abstract}
Abstrak
Kecamatan Bulak merupakan perkampungan nelayan di Surabaya yang padat penduduk dengan kondisi sanitasinya kurang begitu baik. Sejak tahun 2017, ITS bekerjasama dengan National Taiwan University of Science and Technology (NTUST) membantu penyediaan sanitasi. Permasalahan yang terjadi di Bulak saat ini adalah penumpukan kulit kerang dan limbah pengasapan ikan yang belum dikelola. Kerang memiliki kandungan fosfat dan mineral yang bermanfaat untuk nutrisi, demikian juga pada limbah pengasapan ikan, sehingga dari limbah tersebut masih dapat dimanfaatkan menjadi produk pakan/pellet ikan yang memiliki kandungan nutrisi tinggi dan bernilai ekonomi. Pada tahun 2018, nelayan telah memiliki peralatan mesin pencacah kerang tetapi mesin tersebut sudah lama rusak dan tidak dipergunakan sehingga kegiatan pengabdian masyarakat yang dilakukan adalah memperbaiki mesin pembuat pellet dan melakukan pelatihan cara pembuatan pellet skala rumah tangga. Tahapan pertama dilakukan perbaikan mata potong mesin dan saringan, selanjutnya dilakukan dilakukan uji coba untuk pembuatan pelet ikan. Pelet yang telah dibuat dilakukan uji ukuran tepung ikan, karakteristik fisik, organoletptik, daya apung dan proksimat. Hasil uji proksimat pada tepung ikan didapatkan kadar air 5,72; abu 33,15; lemak 18,11; protein 33,26 dan karbohidrat 9,76\%, sedangkan pada pellet menujukkan hasil uji fisik berwarna coklat dengan tekstur agak kasar dan beraroma. Hasil uji proksimat pada pellet menunjukkan kadar air 8,78; abu 23,48; lemak 11,02; protein 27,26 dan karbohidrat $29.46 \%$. Warna pelet coklat muda, tekstur agak kasar, aroma khas dedak dan daya apung selama 50 detik. Hasil pelatihan pada masyarakat juga mendapatkan respon yang bagus bahkan bersemangat untuk membuat home industry produk pellet.
\end{abstract}

\section{Kata Kunci:}

Limbah Pengasapan Ikan, Kulit Kerang, Mesin Pellet, Nelayan, Pelatihan Masyarakat

\section{1 | PENDAHULUAN}

Kecamatan Bulak Kota Surabaya sebagian besar penduduknya adalah sebagai nelayan, sehingga penghasila utama komoditi adalah Ikan Air Laut dengan jumlah produksi mencapai 11,5 ton 1 Permasalahan di lokasi ini terutama berkaitan dengan peningkatan ekonomi masyarakat dan menciptakan akses sanitasi yang sehat. Pada tahun 2018, ITS memulai program Pengabdian pada masyarakat secara internasional di lokasi ini dengan bekerjasama bersama NTUST. Ada beberapa pekerjaan yang dilaksanakan dalam program "Engineer in Action". Melanjutkan kegiatan ini, maka masyarakat di lokasi kegiatan dapat diberdayakan untuk mengolah limbah kerang yang dihasilkan bukan hanya menjadi paving tetapi juga produk lain. Seperti pakan ternak karena kerang ini banyak mengandung calcium (Ca). Selain itu di wilayah ini juga dihasilkan banyak limbah hasil pengolahan ikan untuk ikan asap seperti jeroan, kepala, ekor dan sirip ikan yang ada belum termanfaatkan dengan baik. Sehingga diperlukan alternatif pemanfaatan limbah ikan tersebut, menjadi produk yang bernilai ekonomi tinggi seperti pakan/pelet ikan dan ternak. 
Menurut Rimalia dkk. [1], limbah ikan berupa jeroan, kepala, ekor, dan sirip ikan memiliki kandungan nutrisi protein 29,70\%; lemak 18,83\%; karbohidrat 1,94\%; kadar air 8,97\%; dan serat kasar 1,07\%; sehingga dapat dimanfaatkan sebagai pakan ikan. Pakan dalam bentuk pelet mempunyai beberapa keuntungan, yaitu sifat kering, mudah dikemas, tahan lama dan inovasi kreatif yang memberikan profit sebagai hasil jual yang tinggi.

Berdasarkan fakta tersebut di atas, maka pada pengabdian masyarakat berbasis produk ini, akan dibuat mesin yang dapat membantu proses pemanfaatan limbah kulit kerang dan limbah pengasapan ikan. Mesin ini adalah merupakan produk teknologi tepat guna yang dapat dimanfaatkan langsung oleh masyarakat. Dalam kegiatan PPM ini akan dilaksanakan workshop untuk memberikan sosialisasi pada masyarakat bagaimana mengoperasionalkan dan merawat mesin yang sudah diproduksi oleh ITS. Strategi kegiatan lainnya adalah melakukan uji laboratorium khusus untuk menentukan campuran limbah terbaik yang dapat dimanfaatkan sebagai pakan ikan/pellet ikan. Penelitian di laboratorium meliputi karakteristik dari limbah dan uji proximate untuk mengetahui besarnya protein yang terdapat pada campuran limbah baik dari limbah kerang maupun limbah pengasapan ikan.

\section{2 | METODE}

\subsection{Pembuatan Tepung Ikan dan Tepung Kerang}

Limbah pengasapan ikan didapatkan dari Kecamatan Bulak, Kenjeran Surabaya, dicuci dengan mneggunakan air mengalir hingga bersih. Kemudian kepala ikan asap direbus selama \pm 1,5 jam hingga lunak. Selanjutnya limbah ikan dijemur dibawah sinar matahari selama \pm 5 hari hingga kering dan dilakukan penumbukan dengan lumping hingga cukup halus, dilanjutkan menghaluskan dengan blender dan kemudian disaring sehingga didapatkan tepung ikan.

Cangkang kerang bulu yang didapatkan dari tepi pantai kecamatan Bulak Kenjeran, Surabaya dicuci hingga bersih dengan air mengalir. Dilanjutkan dengan direbus cangkang kerang hingga $\pm 1,5 \mathrm{jam}$. Setelah itu dikeringkan dibawah sinar matahari hingga kering dan dihaluskan dengan lumping hingga halus dan disaring, sehingga didapatkan tepung cangkang kerang.

\section{2 | Pencampuran Adonan Pakan Ikan}

Pencampuran adonan pakan ikan menggunakan komposisi yaitu 40\% tepung dari limbah pengasapan ikan yaitu sebsar 800 gr, dicampur dengan $60 \%$ bahan dasar yang terdiri atas dedak $1080 \mathrm{gr}$, $40 \mathrm{gr}$ tepung tapioka, 20 gr tepung kerang dan $60 \mathrm{gr}$ vitamin konsentrat. Bahan-bahan tersebut dicampurkan hingga rata dan ditambahkan air secukupnya hingga menjadi adonan pakan ${ }^{11}$.

\section{3 | Pencetakan Pakan}

Setelah adonan tercampur dengan rata, selanjutnya adonan pakan didiamkan selama \pm 1 jam. Setelah adonan didiamkan dilanjutkan dengan adonan dicetak dengan alat penggiling daging, lalu dikeringkan dibawah sinar matahari hingga menjadi kering. Pakan disimpan dalam tempat yang bersih dan kering.

\section{4 | Karakterisasi Uji Fisik}

Prosedur pengujian aroma, warna dan tekstur dilakukan dengan melakukan uji organoleptic yang mana pengujian ini dilakukan menggunakan indera manusia dengan pengujian melalui pengelihatan, peraba dan juga penciuman.

Sedangkan pengujian daya apung dilakukan dengan memasukkan pakan sebanyak lima batang ke dalam gelas dengan ketinggian dasar wadah $15 \mathrm{~cm}$ dari permukaan air. Kemudian stopwatch dijalankan tepat setelah pakan ikan ditebar dipermukaan air dan setelah itu dicatat waktu yang dibutuhkan pakan ikan hingga tenggelam ${ }^{[2]}$.

\section{5 | Pengujian Proksimat}

\subsection{1 | Pengukuran Kadar Air dengan Metode SNI 01-2891-1992}

Pengukuran kadar air dilakukan dengan metode oven yaitu yang diawali dengan menimbang sampel pakan sebanyak 1-2 gr, setelah ditimbang dipindahkan ke cawan dan dimasukkan kedalam oven untuk dikeringkan selama 3 jam dengan suhu $105^{\circ} \mathrm{C}$. 
Setalh dikeringkan cawan dipindahkan ke dalam eksikator untuk didinginkan dan kemudian ditimbang dan diulangi hingga mendapatkan bobot yang tetap.

Pengukuran kadar air dengan menggunakan rumus sebagai berikut:

$$
\text { kadarair }=\frac{w}{w_{1}} * 100 \%
$$

dimana $w$ dan $w_{1}$ merupakan bobot cuplikan sebelum dan sesudah dikeringkan dalam satuan gr.

\subsection{2 | Pengukuran Kadar Abu dengan Metode SNI 01-2891-1992}

Hal pertama yang dilakukan adalah dengan menimbang sampel seberat 2-3 gr. Setelah itu dipindahkan kedalam sebuah cawan porselen. Cawan porselen diletakkan diatas nyala pemabakar dan diarangkan, lalu diabukan dalam tanur listrik pada suhu 550 ${ }^{\circ} \mathrm{C}$ sampai pengabuan sempurna dengan sekali-kali pintu tanur dibuka sedikit agar oksigen bisa masuk. Kemudian didinginkan dalam eksikator dan ditimbang hingga bobot tetap.

Pengukuran kadar abu menggunakan rumus sebagai berikut:

$$
\text { kadarabu }=\frac{\left(w_{1}-w_{2}\right)}{w} * 100 \%
$$

dimana $w$ adalah bobot sampel sebelum diabukan, $w_{1}$ adalah bobot sampel dan cawan setelah diabukan, serta $w_{2}$ adalah bobot cawan. Ketiga variabel tersebut memiliki satuan gr.

\subsection{3 | Pengukuran Kadar Protein dengan Metode SNI 01-2891-1992}

Ditimbang 0,51 g sampel yang kemudian dimasukkan kedalam labu kjeldahl $100 \mathrm{ml}$, ditambahkan $2 \mathrm{~g}$ campuran selen (campuran antara 2,5 g serbuk SeO2, $100 \mathrm{~g} \mathrm{~K} 2 \mathrm{SO} 4$ dan $30 \mathrm{~g} \mathrm{CuSO} 45 \mathrm{H} 2 \mathrm{O}$ ) dan $25 \mathrm{ml} \mathrm{H} 2 \mathrm{SO} 4$ pekat. Setelah ditambahkan dilanjutkan dengan dipanskan diatas pemanas listrik atau api pembakar sampai mendidih dan dibiarkan sekita 2 jam hingga larutan menjadi jernih kehijau-hijauan. Kemudian dibiarkan dingin dan diencerkan serta dimasukkan ke dalam labu ukur 100 ml. Diambil dengan pipet $5 \mathrm{ml}$ larutan dan dimasukkan ked ala alat penyuling dan ditambahkan $5 \mathrm{ml} \mathrm{NaOH} \mathrm{30 \%} \mathrm{dan} \mathrm{beberapa} \mathrm{tetes} \mathrm{indikator} \mathrm{PP.}$ Kemudian disulingkan selama kurang lebih 10 menit dan digunakan $10 \mathrm{ml}$ larutan asam borat $2 \%$ yang telah dicampur sebagai panampung. Dibilas ujung pendingin denga air suling dan dititar dengan larutan $\mathrm{HCl}$ 0,01 $\mathrm{N}$ dan dilakukan penetapan blanko.

Perhitungan kadar protein menggunakan rumus sebagai berikut:

$$
\text { kadarprotein }=\frac{\left(V_{1}-V_{2}\right) * N * 0.0014 * f_{k} * f_{p}}{w}
$$

dimana $w$ merupakan bobot sampel, $N$ adalah normalitas $\mathrm{HCl}$, serta $V_{1}$ dan $V_{2}$ merupakan volume $\mathrm{HCl} 0.01 \mathrm{~N}$ yang digunakan penitraan sampel dan blanko. Sementara itu, $f_{k}$ dan $f_{p}$ adalah protein dari bahan yang digunakan dan faktor pengenceran.

\subsection{4 | Pengukuran Kadar Lemak dengan Metode SNI 01-2891-1992}

Pengukuran kadar lemak dengan alat Soxhlet ini dilakukan yaitu dengan menimbang sampel sebanyak 1-2 g dan dimasukkan ke dalam selongsong kertas yang dialasi dengan kapas. Selanjutnya disumbat selongsong kertas yang berisi sampel tersebut dengan kapas dam dikeringkan dalam oven pada suhu yang tidak lebih dari $80^{\circ} \mathrm{C}$ selama kurang lebih 1 jam. Kemudian dimasukkan dalam alat Soxhlet dan dipasang tabung Soxhlet pada labu lemak yang berisi batu didih yang telah dikeringkan dan diketahui bobotnya. Selanjutnya diekstrak dengan heksana atau pelarut lemak lainnya selama kurang lebih 6 jam. Disulingkan heksana dan dikeringkan ekstrak lemak dalam oven pengering pada suhu $105^{\circ} \mathrm{C}$. Didinginkan dan ditimbang serta diulangi pengeringan hingga tercapai bobot tetap. 


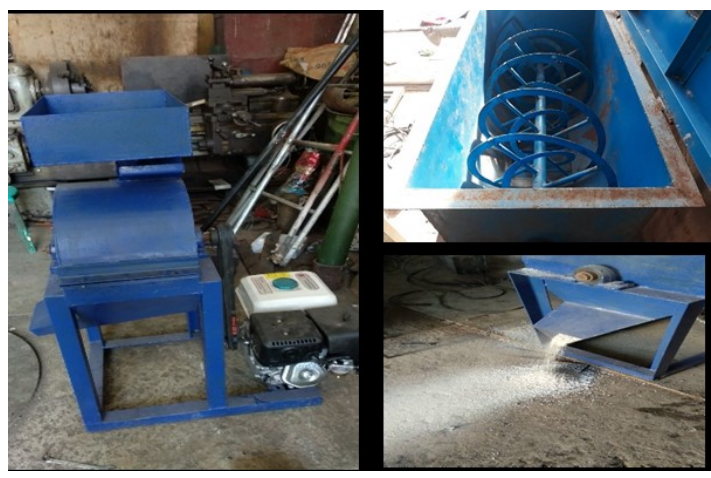

Gambar 1 Mesin pencacah dan pencampur

Perhitungan kadar lemak menggunakan rumus sebagai berikut:

$$
\text { kadarlemak }=\frac{\left(w-w_{1}\right)}{w_{2}} * 100 \%
$$

dimana $w$ adalah bobot sampel, serta $w_{1}$ dan $w_{2}$ adalah adalah bobot lemak sebelum dan sesudah ekstraksi dalam satuan gr.

\subsection{5 | Pengukuran Kadar Karbohidrat dengan Metode SNI 01-2891-1992}

Prosedur Analisa karbohidrat yang dilakukan yaitu menggunakan secara by difference, kadar karbohidrat yang didapat dari hasil pengurangan dari $100 \%$ dengan kadar air, kadar abu, kadar protein dan kadar lemak sehingga kadar karbohidrat bergantung dari faktor pengurangan.

Berikut merupakan rumus untuk perhitungan karbohidrat:

$\%$ karbohidrat $=100 \%-(\% a b u+\%$ air $+\%$ lemak $+\%$ protein $)$

\section{3 | HASIL DAN PEMBAHASAN}

\section{1 | Mesin}

Mesin Pencacah Kerang dan Pencampur Material Pellet ini merupakan alat yang telah ada di Kecamatan Bulak sebelumnya. Namun seiring berjalannya waktu, alat tersebut sudah tidak dapat dioperasikan lagi. Hal ini dikarenakan didalam mesin pencacah kerang dan pencampur material ini terdapat bagian yang harus diganti dan diperbaiki. Maka dalam proyek ini, kami melakukan perbaikan terhadap alat tersebut (Gambar 1 .

Uji coba kedua alat yang telah ada dilakukan untuk dapat mengetahui kekurangan serta hal hal lain yang perlu diperbaiki agar alat tersebut bisa berjalan optimal. Uji coba pertama dilakukan dengan menggunakan kerang yang berasal dari Pantai Kenjeran. Uji coba ini dilakukan pada alat penghancur kerang dan mendapat output yang cukup baik sesuai harapan yaitu ukurannya menyerupai tepung sehingga sesuai dengan bahan baku untuk pelet. Akan tetapi, terdapat beberapa bagian dari saringan yang terlewat oleh kerang sehingga pada beberapa bagian terdapat kerang yang masih utuh dan tidak menjadi bubuk seperti yang diinginkan. Setelah itu dilakukan beberapa perbaruan pada saringan tersebut dengan cara menutup sela sela bagian antara saringan dan body alat penghancur sehingga tidak ada lagi kerang yang lolos tanpa melewati saringan tersebut. Kembali dilakukan uji coba kedua dan hasil yang didapat cukup sesuai dengan yang diinginkan. 
Tabel 1 Kadar proksimat tepung ikan

\begin{tabular}{cc}
\hline Komposisi Kimia & Presentase (\%) \\
\hline Kadar air & 5,72 \\
Kadar abu & 33,15 \\
Kadar lemak & 18,11 \\
Kadar protein & 33,26 \\
Karbohidrat & 9,76 \\
\hline
\end{tabular}

\section{2 | Analisa Proksimat Tepung Ikan}

Tepung ikan merupakan salah satu produk pengolahan ikan dalam bentuk kering yang dijadikan tepung. Tepung ikan merupakan sumber protein yang dibutuhkan pada makanan ternak maupun ikan. Kualitas tepung ikan yang dihasilkan ditentukan dari jenis bahan yang digunakan dan juga teknologi yang digunakan ${ }^{3}$.

Hasil Analisa proksimat pada tepung ikan dapat dilihat pada Tabel 1

Kadar air merupakan jumlah air yang terkandung dalam suatu bahan. Semakin rendah kadar air dalam suatu bahan maka semakin lama penyimpanan bagi suatu produk tersebut, dikarenakan kadar air yang terlalu tinggi dapat menjadi media yang mendukung pertumbuhan dan aktivitas mikroba perusak pangann ${ }^{[4}$. Berdasarkan tabel hasil proksimat yang telah dilakukan didapatkan hasil yaitu pada kandungan kadar air pada tepung ikan yang telah dibuat termasuk dalam kategori yang baik yaitu sebesar $5.72 \%$. Kadar air tersebut masih dibawah kadar maksimum yang ditentukan oleh standar SNI untuk kadar air tepung ikan yaitu maksimal $10 \%$ untuk mutu I dan maksimal $12 \%$ pada mutu II dan II. Rendahnya kadar air yang didapatkan bisa dikarenakan bahan yang digunakan untuk pembuatan tepung ikan merupakan hasil pengasapan, yang mana proses pengasapan melibatkan pemanasan yang dapat mengurangi kandungan air dalam bagian ikan. Selain itu juga terdapat proses penggaraman yang dapat mempengaruhi kandungan air dalam ikan karena ikan bersifat menyerap air melalui proses difusi ${ }^{[4]}$. Pada proses pembuatan tepung juga dilakukan pengeringan yang mana proses tersebut dapat mengurangi kadar air. Hal itu dikarenakan udara memberikan panas yang menyebabkan air dalam bahan menguap, yang selanjutnya udara akan mengangkut uap air yang dibebaskan oleh bahan pangan yang dikeringkan $[5]$.

Kadar abu merupakan campuran dari komponen anorganik atau mineral dalam suatu bahan yang dihasilkan dari sisa pembakaran suatu bahan organik ${ }^{6}$. Berdasarkan hasil proksimat yang diperoleh, didapatkan bahwa kadar abu sebesar 33.15\%. berdasrkan SNI untuk tepung ikan, kadar abu tersebut melewati batas maksimum yang telah ditentukan yaitu maksimum $20 \%$ untuk mutu I, 25\% untuk mutu II dan 30\% untuk mutu III. Tingginya kadar abu tersebut dapat terjadi karena proses pengasapan yang telah dilakukan dan juga pengeringan yang dilakukan pada saat proses pembuatan tepung ikan. Pengasapan dan pengeringan mengakibatkan kadar air semakin menurun sehingga menyebabkan residu yang ditinggalkan juga semakin banyak dalam bahan. Hal tersebut sesuai dengan pernyataan Susanto dan Saneto dalam ${ }^{[3]}$ yang menyatakan kandungan air pada bahan makanan yang dikeringkan akan mengalami penurunan lebih tinggi sehingga menyebabkan pemekatan dari bahan-bahan yang tertinggal salah satunya adalah mineral ${ }^{4}$. Selain proses pengasapan dan pengeringan yang dilakukan, tingginya kadar abu juga bisa disebabkan karena bahan baku yang digunakan dalam pembuatan tepung ikan menggunakan bagian kepala yang mengandung banyak tulang ${ }^{7]}$.

Analisa kadar lemak bertujuan untuk mengetahui kadar lemak yang ada pada tepung ikan. Berdasarkan uji proksimat yang dilakukan kadar lemak yang diperoleh yaitu sebesar $18.11 \%$, yang mana kadar tersebut melebihi kadar maksimum berdasarkan SNI untuk tepung ikan. Batas maksimum lemak untuk tepung ikan berdasarkan SNI adalah 8-12\%. Tingginya kadar lemak yang diperoleh dapat terjadi dikarenakan bahan baku yang digunakan. Ikan yang digunakan pada pembuatan tepung ikan ini antara lain ikan manyung dan juga ikan sembilang. Ikan-ikan tersebut tergolong ikan dengan kadar lemak yang cukup tinggi (berkisar 6\%), sehingga tepung ikan yang dihasilkan juga memiliki kadar lemak yang cukup tinggi. Selain itu suhu dan juga lama pengasapan akan mempengaruhi kadar lemak, suhu yang rendah dan lama pengasapan yang tidak terlalu lama dapat menyebabkan kadar lemak yang masih tinggi. Tingginya kadar lemak juga bisa disebabkan karena reaksi antara panas dan pelekatan komponen asap cair yang bereaksi dengan enzim pada jaringan ikan sehingga menjadikan peningkatan laju perubahan kadar lemak 6 .

Protein merupakan makromolekul yang penting untuk tubuh, dikarenakan protein berfungsi sebagai bahan bakar dalam tubuh dan juga berfungsi sebagai zat pembangun dan juga pengatur ${ }^{-9}$. Berdasarkan hasil uji proksimat yang dilakukan, kadar protein yang diperoleh yaitu sebesar 33.26\%. kadar tersebut masih dibawah minimum dari kadar protein untuk tepung ikan berdasarkan 
Tabel 2 Kadar proksimat pakan ikan

\begin{tabular}{cc}
\hline Komposisi Kimia & Presentase (\%) \\
\hline Kadar air & 8,78 \\
Kadar abu & 23,48 \\
Kadar lemak & 11,02 \\
Kadar protein & 27,26 \\
Karbohidrat & 29,46 \\
\hline
\end{tabular}

SNI yaitu minimum 45-65\%. Meskipun masih dibawah standar SNI, dengan kadar protein tepung ikan 33.26\% tersebut dapat mencukupi kebutuhan protein bagi kerabat ikan channel catfish, yang mana kebutuhan protein optimal ikan channel catfish dan sejenisnya berkisar antara 32-36\% 10. Tidak terlalu tingginya kandungan protein pada tepung ikan yang dibuat dapat terjadi karena proses pemanasan yang berulang, yaitu pengasapan dan pengeringan. Proses pengasapan dan pengeringan menyebabkan struktur protein terdenaturasi, terakogulasi dan menjadi bentuk yang lebih sederhana. Bentuk yang lebih sederhana dari protein menjadikan protein tidak stabil dan menyebabkan perubahan sifat fungsional protein ${ }^{8}$.

Karbohidrat merupakan sumber energi yang memegang peranan utama, yang mana karbohidrat memiliki fungsi sebagai cadangan glikogen, kerja protein cadangan dan efek antiketogenic 11 . Berdasarkan hasil proksimat yang didapatkan kadar karbohidrat pada tepung ikan yang dibuat adalah sebesar $9,76 \%$. Menurut LIPI ${ }^{[12]}$ mengatakan bahwa tepung ikan yang baik yang mengandung maksimal 19\% karbohidrat, sehingga kadar karbohidrat yang dibuat termasuk dalam kategori baik karena masih dibawah 19\%. Kadar karbohidrat pada ikan tidak terlalu tinggi dikarenakan tidak mengandung serat, akan tetapi dalam bentuk glikogen. Karbohidrat setelah diabrbsorbsi oleh sel, glukosa segera diubah menjadi energi atau disimpan dalam tubuh dalam bentuk glikogen ${ }^{[13]}$. Selain itu menurut Winarno dalam ${ }^{[14]}$ kandungan karbohidrat juga sangat dipengaruhi oleh faktor kandungan gizi lainnya. Semakin tinggi kandungan protein, lemak, air dan abu maka semakin rendah kadar karbohidratnya [14].

\section{3 | Analisa Proksimat Pakan Ikan}

Kandungan pada pakan ikan dapat diketahui melalui uji proksimat, sehingga dapat dijadikan evaluasi terhadap pelet yang telah dibuat, apakah sudah memenuhi standar ataukah belum memenuhi.

Hasil uji proksimat yang telah dilakukan pada pelet ikan dapat dilihat pada Tabel 2

Kadar air yang didapatkan pada pengujian proksimat pelet ikan sebesar 8,76\%. Kadar air tersebut masih sesuai dengan SNI pakan ikan yang mana kandungan air maksimal sebesar $12 \%$ sehingga dapat dikatakan pakan ikan yang dibuat memiliki kualitas yang baik. Kadar air yang didapatkan dalam pengujian proksimat tidak terlalu tinggi, hal itu dikarenakan proses penjemuran pakan ikan setelah dicetak sehingga kadar air dala pakan mengalami penguapan. Kadar air dalam pakan mutlak dibutuhkan, akan tetapi dengan jumlah yang sedikit. Pakan ikan yang mengandung banyak air akan lebih mudah ditumbuhi oleh mikroba dan disukai oleh serangga, dengan kadar air yang tinggi pada pakan ikan juga menyebabkan pakan ikan lebih mudah rusak. Selain itu juga kadar air memepengaruhi tekstur, penampakan dan juga cita rasa dari pakan tersebut. Kadar air merupakan parameter yang digunakan untuk penentuan penyimpanan pakan dan juga sebagai parameter yang terlibat dalam kebanyakan reaksi kerusakan bahan pangan seperti pertumbuhan mikroba, pencoklatan, hidrolisis dan juga oksidasi lemak ${ }^{[15]}$.

Abu merupakan residu yang dihasilkan oleh pembakaran bahan organic yang berupa bahan anorganik dalam bentuk oksida, garam dan juga mineral ${ }^{[16]}$. Hasil proksimat yang dilakukan pada pakan ikan didapatkan kadar abu sebesar 23,48\%, yang mana hasil tersebut dalam kategori yang tinggi, dikarenakan menurut SNI kadar abu untuk pakan ikan yaitu $<12 \%$. Tingginya kadar abu pada pelet dikarenakan bahan-bahan yang digunakan pada pembuatan pelet ini mengandung mineral yang cukup tinggi. Tepung ikan yang digunakan pada pembuatan pelet ini mengandung kadar abu berdasarkan uji proksimat yang dilakukan sebesar $33 \%$. Selain itu pada bahan pakan ikan ini juga terdapat dedak, tepung tapioka dan juga cangkang kerang, yang mana cangkang kerang ini mengandung kalsium yang cukup tinggi yaitu berkisar 30-40\%, sedangkan dedak yang digunakan juga mengandung abu, kalsium dan fosfor yitu sebesar 6,6-9,9 gr, 30-120 mg, dan 1100-2500 mg per 100 gram beras dan tepung tapioka sebesar $0,1 \%$ [17 $[18$. Sehingga kadar abu yang didapatkan pada pakan ikan tersebut termasuk tinggi. Kadar abu yang didapatkan pada pakan ikan belum memenuhi Standar SNI untuk pakan ikan. Tingginya kadar abu dalam pakan dapat menyebabkan penghambatan pertumbuhan dari ikan yang mengonsumsi, karena ikan hanya membutuhkan mineral dalam jumlah yang sedikit, yang mana kadar mineral dalam pakan digunakan untuk pertumbuhan gigi dan juga sisik $[16]$. 
Lemak merupakan sumber energi utama, yang mana lemak menghasilkan energi yang jauh lebih besar dibandingkan dengan karbohdurat ataupun protein. Akan tetapi karena ikan memiliki kemampuan yang sangat baik dalam mengkonsumsi protein, peranan lemak sebagai sumber energi menempati kedudukan kedua setelah protein ${ }^{16}$. Selain itu lemak juga dapat meningkatkan nilai kalori, mengurangi efek berdebu/memperbaiki tekstur dan dapat meningkatkan palatabilitas, sehingga dapat mengurangi feed lost dalam proses peleting dan juga pemberiannya ${ }^{[20}$. Berdasarkan hasil proksimat dari pengujian pakan ikan yang dibuat, didapatkan kadar lemak sebesar 11,02\%, sedangkan menurut standar SNI kadar lemak untuk pakan ikan sebesar 2-10\%. Sehingga kadar lemak dari pakan ikan yang telah dibuat masih terlalu tinggi dan belum memenuhi standar SNI pakan ikan. Cukup tingginya kadar lemak yang terkandung dalam pakan ikan disebabkan karena kandungan lemak pada bahan yang digunakan. Kandungan lemak pada bahan yang digunakan yaitu sebesar $18.11 \%$ untuk tepung ikan, dedak 15-19,7 gram/100 gram beras atau $15-19,7 \%$ dan tepung tapioka sebesar 0,5\%. Sumber lemak utama pada pakan ikan ini adalah tepung ikan dan dedak, dikarenakan dalam kedua bahan tersebut memiliki kadar lemak yang lebih tinggi dibandingkan dengan kadar lemak bahan yang lainnya. Penggunaan lemak dalam pakan haruslah dalam jumlah yang maksimum dikarenakan kelebihan lemak dalam pakan dapat menyebakan nutrional pathology yaitu seperti penumpukan lemak dan degenerasi hati ikan yang mengkonsumsi. Selain itu penumpukan lemak dalam tubuh ikan dapat mempengaruhi cita rasa dari daging ikan ${ }^{21]}$.

Protein merupakan sumber asam amino esensial yang berfungsi untuk mendukung pertumbuhan yang oprimum dan juga sebagai sumber energi bagi ikan. Selain itu protein dala pakan juga berfungsi untuk mempertahankan fungsi dari jaringan tubuh yang lebih vital 16 21]. Karena protein merupakan sumber energi pada ikan, maka jika kebutuhan protein tidak terpenuhi akan menyebabkan penurunan drastic atau penghentian pertumbuhan atau kehilangan bobot tubuh, dikarenakan ikan akan menarik Kembali protein dari beberapa jaringan sebagai bentuk pertahanan fungsi dari jaringan yang lebih vital 22$]$. Berdasarkan hasil proksimat yang dilakukan pada pakan ikan yang telah dibuat, didapatkan kadar protein yaitu sebesar $27,26 \%$, sedangkan kadar protein pada pakan ikan yang baik menurut standar SNI 2006 sebesar 20-35\%. Oleh karena itu kadar protein dari pakan ikan yang telah dibuat masih memenuhi stnadar SNI untuk pakan ikan. Kadar protein pada pakan ikan dipengaruhi oleh kandungan protein pada bahan yang digunakan. Kadar protein pada bahan yang digunakan yaitu sebesar $33.26 \%$ untuk tepung ikan, dedak sebesar 11,3-14,9\%, tepung tapioka yaitu 1,1\% dan pada cangkang kerang sebsar 3\%. Sumber utama protein pada pakan ikan yang telah dibuat berasal daritepung ikan. Tidak terlalu tingginya kadar protein pada pakan ikan dapat disebabkan karena proses penjemuran yang dilakukan setelah proses pencetakan, yang mana pemanasan yang terlalu lama dengan suhu yang tinggi dapat menyebabkan denaturasi pada protein, yang mana denaturasi ini dapat menyebabkan rusaknya kondisi fisik protein sehingga sifat alamiahnya berubah ${ }^{[19}$. Selain itu tidak dilakukannya fermentasi pada proses pembuatan pakan ikan dapat menyebabkan kurang tingginya kadar protein. Hal itu dikarenakan fermentasi dapat membantu meningkatkan kadar protein pada pakan, dikarenakan dengan fermentasi dapat memecah bahan yang tidak mudah dicerna dengan bantuan mikroorganisme. Enzim yang dihasilkan dalam proses fermentasi dapat memperbaiki nilai nutisi seperti protein dan nutsrisi yang lainnya ${ }^{23}$.

Karbohidrat merupakan salah satu makro nutrient yang dibutuhkan oleh ikan sebagai sumber energi pendukung pertumbuhan ikan, oleh karena itu karbohidrat sering ditambahkan untuk pemeliharaan tubuh. Selain itu karbohidrat merupakan sparing effect bagi protein sehingga keberadaan karbohidrat dalam pakan harus dapat dimanfaatkan secara efisien sebagai sumber energi ikan. Bila terjadi kelebihan energi karbohidrat maka karbohidrat tersebut akan disimpan dalam bentuk glikogen yang digunakan sebagai cadangan energi serta sebagai sintesis asam-asam amino non esensial (protein) dan lemak ${ }^{[24}$. Berdasarkan hasil proksimat yang dilakukan pada pakan ikan yang telah dibuat, didapatkan kadar karbohidrat sebesar $29,46 \%$. Kadar karbohudrat pada pakan ikan tersebut berasal dari bahan yang digunakan pada pembuatan pakan ikan, yang mana kadar karbohidrat pada bahan sebesar $9.76 \%$ pada tepung ikan, 34-62\% pada dedak dan tepung tapioka sebesar $88 \%$. Karbohidrat dalam pakan dimanfaatkan oleh ikan ditentukan oleh kadar dalam pakan, jenis dan ukuran ikan dan juga ketersediaan enzim pencernaan dan hormone metabolism karbohidrat. Untuk jenis ikan yang mana ikan-ikan golongan karnivora memiliki kemampuan yang lebih rendah dalam memanfaatkan karbohidrat jika dibandingkan dengan ikan golongan omnivora, yang mana golongan karnivora hanya mampu memanfaatkan karbohidrat maksimal 30\%, sedangkan omnivore dapat mencapai 50\% 16. 24]. Berdasarkan hal tersebut karbohidrat dalam pakan ikan yang telah dibuat dapat memenuhi kebutuhan ikan, yang mana kebutuhan akan karbohidrat pada ikan bergantung dari jenis ikan yang akan diberi pakan. 


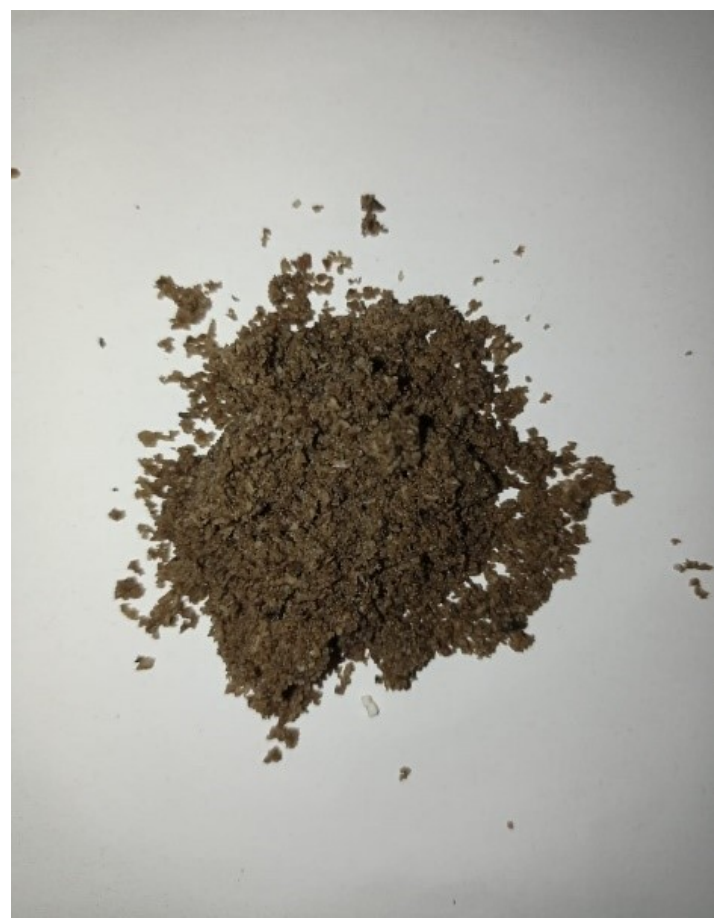

Gambar 2 Karakteristik fisik tepung ikan

\section{4 | Karakteristik Uji Fisik}

\subsection{1 | Tepung Ikan}

Hasil karakteristik uji fisik yang dilakukan pada tepung ikan meliputi warna, tekstur dan aroma pada pada tepung ikan. Gambar 2 menunjukan pellet ikan yang sudah terbentuk.

Warna menjadi salah satu parameter yang penting yang digunakan yang dapat menentukan kualitas dari produk yang ditentukan [25]. Berdasarkan gambar diatas dapat dilihat bahwa tepung ikan yang dihasilkan memiliki warna coklat kehitaman. Hal itu dikarenakan bahan baku yang digunakan merupakan kepala ikan asap yang memiliki warna coklat keemasan. Perubahan warna yang terjadi pada pengasapan ikan dihasilkan oleh reaksi kimia fenol dengan oksigen yang ada di udara dan dikatakan juga bahwa pembentukan warna pada ikan asap dikarenakan reaksi Maillard, yaitu rekasi yang terjadi antara karbohidrat dengan gugus amina primer yang terdapat pada bahan yang akan menghasilkan bahan berwarna coklat yang disebut melanoidin [26 [27]. Warna coklat pada tepung ikan juga dapat menunjukkan kadar lemak yang ada pada tepung tersebut dalam kadar yang cukup tinggi, dibuktikan dengan uji proksimat yang dilakukan pada tepung ikan yang ada pada Tabel 1 Lemak yang terkandung dalam bahan dapat menyebabkan oksidasi yang menghasilkan warna coklat ${ }^{13}$. Selain dari bahan baku yang digunakan, proses pengolahan yang dilakukan dala pembuatan tepung ikan juga dapat menyebabkan warna tepung ikan menjadi coklat kehitaman, seperti perlakuan perebusan dan juga pengeringan. Perlakuan pemanasan yang dilakukan dapat menyebabkan reaksi browning nonenzimatik yaitu karbohidrat yang akan bereaksi dengan protein bila ada panas 28.

Selain warna, tekstur juga menjadi parameter kualitas dari suatu produk. Pada tepung ikan yang dihasilkan memiliki tekstur yang cukup halus. Bahan yang digunakan pada pembuatan ini adalah kepala ikan yang mana sebagian besar berupa tulang sehingga tepung yang dihasilkan masih terdapat tulang kecil-kecil dan tidak terlalu halus. Selain warna dan tekstur, aroma juga menjadi parameter kualitas dari produk yang dihasilkan. Pada tepung ikan yang dihasilkan ini memiliki aroma gurih. Aroma gurih ini dihasilkan dari ikan asap yang menjadi bahan baku. Aroma tersebut didapatkan dari proses pengasapan yaitu oleh senyawa asam, fenol, aldehid dan zat-zat lain sebagai pembantu untuk menghasilkan rasa tersebut. Senyawa fenol memberikan aroma pungent, eresoline, manis asap dan seperti bau 26$]$ 29. 


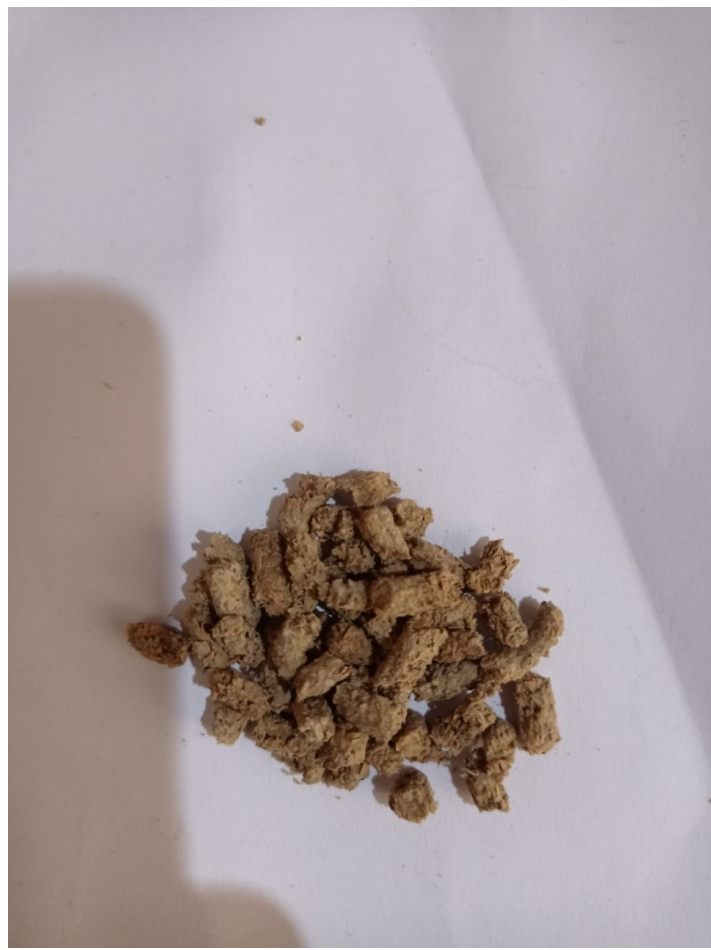

Gambar 3 Karakteristik fisik pelet ikan

Tabel 3 Data parameter karakteristik uji fisik pakan ikan

\begin{tabular}{cc}
\hline Parameter yang Diuji & Rata-rata \\
\hline Warna & Coklat muda \\
Tekstur & Agak kasar \\
Aroma & Khas dedak \\
Daya apung (dalam detik) & $00: 50: 08$ \\
\hline
\end{tabular}

\subsection{2 | Pakan Ikan}

Hasil karakterisasi uji fisik yang dilakukan pada pelet/pakan ikan meliputi tekstur, aroma dan warna pada pakan, serta data rata-rata parameter uji fisik pada pakan ikan yaitu daya apung. Gambar 3 adalah pelet ikan yang sudah berbentuk pelet siap dipasarkan.

Sedangkan hasil karakterisasi uji fisik pada pakan ikan disajikan dalam Tabel 3

Berdasarkan tabel mengenai hasil karakterisasi uji fisik pada pakan ikan didapatkan warna pada pakan tersebut yaitu coklat muda, warna tersebut didapatkan dari bahan dedak, yang mana komposisi bahan paling pada pembuatan pakan ikan tersebut merupakan bahan dengan komposisi yang paling banyak. Sehingga didapatkan warna pakan ikan yaitu coklat muda. Pada dasarnya warna pakan tidak mempengaruhi palatabilitas hewan ternak terhadap konsumsi pakan tersebut. Karena faktor yang mempengaruhi adalah aroma dan rasa dari suatu bahan pakan. Karakteristik warna pada pakan ikan tidak mempengaruhi penerimaan ikan dalam mengkonsumsi pakan tersebut, akan tetapi berpengaruh terhadap daya Tarik terhadap konsumen dalam memilih 30$]$.

Selain warna, tesktur juga dapat menjadi parameter dari kualitas pakan tersebut. Tekstur yang didapatkan pada pakan ikan ini agak kasar, yang mana hal itu dikarenakan bahan yang digunakan dalam pakan ini. Faktor yang mempengaruhi adalah tingkat kehalusan bahan, jenis perekat dan juga jumlah perekat yang digunakan. Semakin halus bahan yang digunakan dapat meningkatkan kapasitas konsumsi yang akan mempengaruhi laju dan juga kecernaan pakan yang dapat meningkatkan metabolism penyerapan. Ukuran partikel dalam bahan yang semakin kecil juga dapat memperluas area permukaan partikel 
sehingga dapat menyebabkan interaksi kimia yang lebih optimal dalam penyerapan nutrisi ke dalam sel [30]. Selain bahan pengolahan dalam pencetakan pelet juga mempengaruhi tekstur dari pakan ikan. Pada pengolahan ini masih dilakukan secara manual sehingga pakan yang dihasilkan tidak sehalus pakan komersil dari pabrik yang sudah menggunakan peralatan yang lebih baik [31].

Aroma pakan ikan merupakan hal yang penting untuk dapat meningkatkan palatabilitas ikan dalam mengkonsumsi pakan tersebut. Faktor yang mempengaruhi aroma dari pakan ikan berasal dari bahan yang digunakan untuk pembuatan ${ }^{30}$. Pada pakan ikan yang telah dibuat memiliki aroma yang khas dari dedak. Hal itu dikarenakan komposisi dedak yang paling banyak digunakan pada pembuatan pakan ini, Aroma khas dedak ini memiliki aroma yang tidak terlalu menyengat, sehingga mungkin ikan tidak mengenali keberadaan pakan ikan tersebut Ketika diberikan. Agar dapat menarik atau meningkatkan palabilitas ikan terhadap pakan tersebut, biasanya pakan ditambahkan zat atraktan, yang mana zat ini dapat meningkatkan asupan pakan, pertumbuhan dan juga konsumsi ikan terhadap pakan. Ketertarikan ikan terhadap pakan merupakan hal yang sangat penting dalam formulasi pakan. Karena keseimbangan nutrisi menjadi kurang efektif jika pakan ikan tidak mengandung komponen yang dapat memacu respons ikan terhadap pakan tersebut ${ }^{32]}$.

Daya apung merupakan waktu yang diperlukan oleh pakan setelah ditebar hingga tenggelam di dasar ${ }^{33}$. Berdasarkan uji yang dilakukan pada pakan ikan mengenai daya apung didapatkan rata-rata waktu yaitu 50 detik. Daya apung dari pakan dipengaruhi oleh berat jenis pakan, yang mana semakin besar berat jenis pada pakan dibandingkan dengan berat jenis air (BJ air =1), maka pakan akan cepat tenggelam ${ }^{34}$. Selain itu proses pengolahan juga mepengaruhi yang mana berdasarkan penelitian Zaman dkk. ${ }^{35]}$ perlakuan fermentasi dapat memunculkan daya apung yang setara dengan kemampuan mengapung yang dimunculkan oleh mesin ekstruder yang dihasilkan dari pabrik, yang mana pada penelitian tersebut pakan ikan mengapung selama 3 jam. Pada pembuatan pakan ikan ini tidak dilakukaknnya fermentasi dan juga peralatan yang digunakan juga msih sederhana sehingga dapat mempengaruhi daya apung pada pelet yang telah dibuat. Oleh karena itu, pakan yang telah dibuat ini termasuk kedalam kategori pakan tenggelam.

\section{4 | KESIMPULAN}

Berdasarkan penelitian yang telah dilakukan dapat disimpulkan:

- Mesin yang sudah diperbaiki dapat menghasilkan tepung kerang dengan tekstur yang halus.

- Uji proksimat yang dilakukan pada tepung ikan menunjukkan hasil kadar air 5,72; abu 33,15; lemak 18,11; protein 33,26 dan karbohidrat $9,76 \%$. Kadar yang dihasilkan tersebut dipengaruhi oleh bahan yang digunakan yaitu jenis ikan dan juga proses pengolahan kepala ikan hingga menjadi tepung ikan.

- Uji proksimat pada pakan ikan menunjukkan hasil kadar air 8,78; abu 23,48; lemak 11,02; protein 27,26 dan karbohidrat 29,46\%. Kadar tersebut dipengaruhi oleh komposisi dan kandungan nutrisi dari bahan-bahan yang digunakan.

- Uji fisik yang dilakukan pada tepung ikan menghasilkan warna coklat, tekstur yang agak kasar dan aroma gurih dan pada pakan ikan menghasilkan warna coklat muda, tekstur yang agak kasar dengan aroma khas dedak serta digunakan maka semakin baik pakan ikan yang dihasilkan.

- Hasil pelatihan pada masyarakat juga mendapatkan respon yang bagus bahkan bersemangat untuk membuat home industry produk pellet.

\section{5 | UCAPAN TERIMA KASIH}

Terima kasih kami sampaikan kepada:

- DRPM ITS yang telah memberikan dana untuk kegiatan ini melalui kontrak nomer: 1006/PKS/ITS/2020

- Aparat Desa dan Nelayan di Kampun Bulak Kenjeran yang telah berpartisipasi dalam kegiatan pelatihan maupun pembuatan pellet.

- Mahasiswa KKN yang terlibat dalam kegiatan ini 


\section{Referensi}

1. Rimalia A. Pengaruh Limbah Ikan Terhadap Pertumbuhan, Kualitas Darah dan Kandungan Protein Ikan Patin (Pangasius hypothalamus HB). Yogyakarta, Indonesia: UGM Press; 2002.

2. Aslamyah S, Karim MY. Uji organoleptik, fisik dan kimiawi pakan buatan untuk ikan bandeng yang disubstitusi dengan tepung cacing tanah (Lumbricus sp.). Jurnal Akuakultur Indonesia 2012;11:124-131.

3. Sipayung MY, Suparmi S, Dahlia D. Pengaruh Suhu Pengukusan Terhadap Sifat Fisika Kimia Tepung Ikan Rucah. Riau, Indonesia: Riau University Press; 2015.

4. Swastawati F, Sumardianto S, Indiarti R. Perbandingan Kualitas Ikan Manyung Asap Menggunakan Liquid Smoke Kayu Pinus dengan Konsentrasi yang Berbeda. Indonesian Journal of Fisheries Science and Technology 2006;2(1):29-39.

5. Zuhri NM, Swastawati F, Wijayanti I. Pengkayaan kualitas mi kering dengan penambahan tepung daging ikan lele dumbo (Clarias gariepinus) sebagai sumber protein. Jurnal Pengolahan dan Bioteknologi Hasil Perikanan 2014;3(4):119-126.

6. Yunita N, Hasan B, Leksono T. Evaluasi Mutu Kimia, Sensoris dan smoking Yield Baung (Hemibagrus nemurus) Hasil Budidaya yang Diasap dengan Lama Pengasapan Berbeda. Jurnal Online Mahasiswa Fakultas Perikanan dan Ilmu Kelautan 2017; .

7. Erlania. Eksistensi Industri Tepung Ikan di Kota Tegal, Jawa Tengah. Media Akuakultur 2012;7(1):39-43.

8. Prasetyo DYB, Darmanto YS, Swastawati F. Efek perbedaan suhu dan lama pengasapan terhadap kualitas ikan bandeng (Chanos chanos Forsk) cabut duri asap. Jurnal Aplikasi Teknologi Pangan 2015;4(3).

9. Natsir NA. Analisis Kandungan Protein Total Ikan Kakap Merah dan Ikan Kerapu Bebek. BIOSEL (Biology Science and Education): Jurnal Penelitian Science dan Pendidikan 2018;7(1):49-55.

10. Utomo NBP, Setiawati M. Peran Tepung Ikan dari berbagai bahan baku terhadap pertumbuhan lele sangkuriang. Jurnal Akuakultur Indonesia 2013;12(2):158-168.

11. Jayadi YI, Rahman A. Analisis Kandungan Gizi Makro pada Ikan Duo (Penja) Hitam dan Putih sebagai Pangan Lokal Kota Palu. Jurnal Gizi dan Kesehatan 2013;2(1).

12. LIPI. Formulasi biskuit dengan substitusi tepung ikan lele dumbo (Clarias gariepinus) dan isolat protein kedelai (Glycine max) sebagai makanan potensial untuk anak balita gizi kurang. J Teknol Dan Industri Pangan 2021;23(1):9-16.

13. Lunda N, Ibrahim MN, Suwarjoyowirayatno S. PEMANFAATAN HASIL SAMPING PENGOLAHAN IKAN PEPEREK (Leiognathus equulus) MENJADI TEPUNG IKAN. Jurnal Fish Protech 2019;2(1).

14. Ndahawali DH, Ondang HM, Tumanduk N, Ticoalu F, Rakhmayeni DA. Pengaruh Lama Waktu Pengasapan Dan Waktu Penyimpanan Terhadap Kandungan Gizi Ikan Tandipan (Dussumieria SP). FRONTIERS: JURNAL SAINS DAN TEKNOLOGI 2019;1(3).

15. Mulia DS, Wulandari F, Maryanto H. Uji Fisik Pakan Ikan yang Menggunakan Binder Tepung Gaplek (Physical Test of Fish Feed Using Cassava Flour Binder). Jurnal Riset Sains dan Teknologi 2017;1(1):37-44.

16. Gunawan G, Khalil M. Analisa proksimat formulasi pakan pelet dengan penambahan bahan baku hewani yang berbeda. Acta Aquatica: Aquatic Sciences Journal 2015;2(1):23-30.

17. Astawan M, Febrinda AE. Potensi dedak dan bekatul beras sebagai ingredient pangan dan produk pangan fungsional. Jurnal Pangan 2010;19(1):14-21.

18. Basri TH, Nuraini dan Sri RP. Pengolahan Cangkang Tiram Menjadi Grit dan Tepung Cangkang Tiram di Gampong Kuala Langsa Kecamatan Langsa Barat. Prosiding Seminar Nasional MIPA III 2017;. 
19. Widaksi CP, Santoso L, Hudaidah S. Pengaruh Substitusi Tepung Ikan Dengan Tepung Daging Dan Tulang Terhadap Pertumbuhan Patin (Pangasius sp.). Jurnal Rekayasa dan Teknologi Budidaya Perairan 2014;3(1):303-312.

20. Haetami K. EFEKTIFITAS LEMAK DALAM FORMULASI TERHADAP KUALITAS PELET DAN PERTUMBUHAN IKAN NILA. Jurnal Pengabdian Kepada Masyarakat 2018;2(1):6-11.

21. Usman U, Palinggi NN, Kamaruddin K, Makmur M, Rachmansyah R. Pengaruh Kadar Protein dan Lemak Pakan terhadap Pertumbuhan dan Komposisi Badan Ikan Kerapu Macan, Epinephelus Fuscoguttatus. Jurnal Riset Akuakultur 2010;5(2):277-286.

22. Iskandar R, Fitriadi S. Analisa Proksimat Pakan Hasil Olahan Pembudidaya Ikan di Kabupaten Banjar Kalimantan Selatan. Ziraa'ah Majalah Ilmiah Pertanian 2017;42(1):65-68.

23. Yulianingrum T, Pamukas NA, Putra I. Pemberian Pakan Yang Difermentasikan Dengan Probiotik Untuk Pemeliharaan Ikan Lele Dumbo (Clarias Gariepinus) Pada Teknologi Bioflok Feed Fermented Using Probiotic for African Catfish in Biofloc Technology . Riau, Indonesia: Riau University Press; 2017.

24. Yanto H, Setiadi AE, Kurniasih D. Pengaruh Tingkat Karbohisrat Berbeda dalam Pakan Terhadap Kinerja Pertumbuhan Ikan Tengadak (Barbonymus schawenfeldii). Jurnal Ruaya 2019;7(2).

25. Dinar L, Suyantohadi A, Fallah MAF. Pendugaan kelas mutu berdasarkan analisa warna dan bentuk biji pala (Myristica fragrans houtt) menggunakan teknologi pengolahan citra dan jaringan saraf tiruan. Jurnal Keteknikan Pertanian 2012;26(1).

26. Sulistijowati R, Djunaedi DS, Nurhajati J, Afrianto E, Udin Z. Mekanisme Pengasapan Ikan. Bandung, Indonesia: UNPAD Press; 2011.

27. Arvianto AA, Swastawati F, Wijayanti I. Pengaruh Fortifikasi Tepung Daging Ikan Lele Dumbo (Clarias gariepinus) terhadap Kandungan Asam Amino Lisin pada Biskuit. Jurnal Pengolahan dan Bioteknologi Hasil Perikanan 2016;5(4):20-25.

28. Fatmawati F, Mardiana M. Analisa tepung ikan gabus sebagai sumber protein. OCTOPUS: Jurnal Ilmu Perikanan 2014;3(1):236-243.

29. Suroso E, Utomo TP, Hidayati S, Nuraini A. Pengasapan Ikan Kembung Mneggunakan Asap Cair Dari Kayu Karet Hasil Redestilasi. Jurnal Hasil Perikanan Indonesia 2018;21(1).

30. Handayani IS, Tampubolon BIM, Subrata A, Pujaningsih RI. Evaluasi Organoleptik Multinutrien Blok yang dibuat dengan Menggunakan Metode Dingin pada Perbedaan Aras Molases. Jurnal Ilmu Nutrisi dan Teknologi Pakan 2019;17(3):64-68.

31. Safitri NM, Aminin A, Luthfiyah S. Pembuatan Formulasi Pakan Apung Ikan Berbahan Baku Lokal. Jurnal Perikanan Pantura 2020;3(1):31-37.

32. Khasani I. Atraktan pada Pakan Ikan: Jenis, Fungsi, dan Respons Ikan. Media Akuakultur 2013;8(2):127-134.

33. Afrianto, Eddy, L E. Pakan Ikan. Yogyakarta, Indonesia: Kanisius; 2005.

34. Yulianto T. Uji Stabilitas, Daya Apung dan Warna serta Aroma pada Pelet yang Berbeda. Dinamika Maritim 2018;6(2):5-8.

35. Zaman AB, Sriherwanto C, Yunita E, Suja'i I. Karakteristik Fisik Pakan Ikan Apung Non-Ekstrusi Yang Dibuat Melalui Fermentasi Rhizopus oryzae. Jurnal Bioteknologi dan Biosains Indonesia 2018;5(1):9-16.

Cara mengutip artikel ini: Ashuri N.M., Nurhayati A.P.D., Warmadewanthi I.D.A.A., Saptarini D., Putra A.B.K., Bagastyo A.Y., Herumurti W., Rachmada A.F., (2021), Pemanfaatan Limbah Kulit Kerang dan Limbah Sisa Pengolahan Ikan di Kecamatan Bulak Kota Surabaya, Sewagati : Jurnal Pengabdian Kepada Masyarakat, 5(3):227-239. 